\title{
Molecules to Mountains: A Multi-Proxy Investigation Into Ancient Climate and Topography of the Pacific Northwest, USA
}

\author{
Alexander McLean * and John Bershaw \\ Department of Geology, Portland State University, Portland, OR, United States
}

We characterize the topographic evolution of the Pacific Northwest, United States, during the Cenozoic. New paleosol carbonate stable isotope $\left(\delta^{18} O\right)$ results from central Oregon are presented, along with published proxy data, including fossil teeth, smectites, and carbonate concretions. We interpret a polygenetic history of Cascade Mountain topographic uplift along-strike, characterized by: 1) Steady uplift of the Washington Cascades through the Cenozoic due long-term arc rotation and shortening against a Canadian buttress, and 2) Uplift of the Oregon Cascades to similar-to-modern elevations

Edited by:

Alexis Licht

University of Washington, United States

Reviewed by: Aude Gebelin, University of Plymouth,

United Kingdom

Gregory Retallack,

University of Oregon, United States

*Correspondence:

Alexander McLean

amclean1917@gmail.com

Specialty section:

This article was submitted to

Quaternary Science, Geomorphology

and Paleoenvironment,

a section of the journal

Frontiers in Earth Science

Received: 01 November 2020

Accepted: 18 February 2021

Published: 26 March 2021

Citation:

McLean A and Bershaw J (2021) Molecules to Mountains: A Multi-Proxy Investigation Into Ancient Climate and

Topography of the Pacific Northwest, USA.

Front. Earth Sci. 9:624961. doi: 10.3389/feart.2021.624961 by the late Oligocene, followed by topographic stagnation as extension developed into the Neogene. Since the Miocene, meteoric water $\delta^{18} \mathrm{O}$ values have decreased in Oregon, possibly due to emergence of the Coast Range and westward migration of the coastline. Spatial variability in isotopic change throughout the Pacific Northwest suggests that secular global climate change is not the primary forcing mechanism behind isotopic trends, though Milankovitch cycles may be partly responsible for relatively short-term variation.

Keywords: paleoclimate, cascades, stable isotope, topography, oregon coast range

\section{INTRODUCTION}

Stable isotope ratios of water illuminate temporal changes in a region's climate and topography (e.g. Savin, 1982; Garzione et al., 2000; Rowley and Garzione, 2007). Oxygen $\left(\delta^{18} \mathrm{O}\right)$ isotope ratios in pedogenic carbonates have been utilized to constrain paleoclimate (Cerling and Quade, 1993; Quade et al., 2007). While studies have looked at Cascade Mountain uplift using single proxies for analysis (e.g. Kohn et al., 2002; Kohn and Law, 2006; Bershaw et al., 2019), few comprehensive studies have taken a multi-proxy approach.

Considering multi-proxy stable isotope data can reduce uncertainty by constraining forcing mechanisms of isotopic change (e.g. Gébelin et al., 2012; Currie et al., 2016). We present new soil carbonate $\delta^{18} \mathrm{O}$ data and synthesize existing paleowater proxy data to provide a more comprehensive interpretation of spatial (Pacific Northwest) and temporal (Cenozoic) patterns. Further, by comparing temporal patterns of stable oxygen isotopes in the Pacific Northwest to the record of global Cenozoic $\delta^{18} \mathrm{O}$ change and Milankovitch-scale variation (e.g. Zachos et al., 2001), the influence of global climate relative to local topography changes is investigated. 


\section{BACKGROUND}

The Pacific Northwest is in the mid-latitudes of the northern hemisphere. Orographic precipitation is significant in mountains across the region, including the Cascade Volcanic Arc (Cascades), the Olympic Mountains in Washington, and the Oregon Coast Range. The Cascade Mountains' rainshadow is associated with significant differences in precipitation amount on either side of the range. Average precipitation along at roughly $-122^{\circ}$ longitude (windward) ranges from $150-210 \mathrm{~cm} /$ year, while average precipitation at $-121^{\circ}$ longitude (lee) ranges from $22-25 \mathrm{~cm} /$ year (Figure 1A). Westerly air-flow patterns in the region are interpreted to have remained relatively constant during the Cenozoic based on depositional patterns of wind-blown ash (Robinson et al., 1990).

In Oregon and Washington, the Cascades extend northsouth from British Columbia, Canada, to CA, United States. The Cascades are a magmatic arc that formed from the subduction of the Juan de Fuca Plate under the North American Plate (Priest, 1990). The onset of Cascade volcanism is interpreted to have begun $\sim 45 \mathrm{Ma}$ (Wells and McCaffrey, 2013). By $235 \mathrm{Ma}$, the entire magmatic arc had been established from northern California to Mt. Rainier (Priest, 1990). The Clarno Formation of central Oregon (Bestland et al., 1999), Siletz River, and Crescent Formations of Washington contain significant amounts of subaerial volcanic rock that erupted as early as $51 \mathrm{Ma}$ (Wells et al., 2014), suggesting some terrestrial settings by that time. The first plutons of the Cascade arc appeared at $26 \mathrm{Ma}$ (du Bray and John, 2011), with a significant volume of ignimbrites erupting starting at $39 \mathrm{Ma}$ (Robinson et al., 1984). Volcanic activity slowed greatly between 17-10 Ma (Priest, 1990). In the mid-Miocene, the Columbia
River Flood Basalt Group (CRBG) inundated much of Oregon and southern Washington (Beeson et al., 1989; Sherrod and Smith, 2000). They are absent in the Cascades themselves, suggesting the Cascades served as a topographic barrier. In the Late Miocene, further volcanic activity is evidenced by ash deposition and volcaniclastics of the Deschutes Formation and widespread Rattlesnake Tuff (Smith et al., 1987; Streck and Grunder 1995).

We present new $\delta^{18} \mathrm{O}$ from paleosol carbonates from the lee side of the Cascades in Central Oregon (Figure 1B). Additionally, we synthesize published stable isotope data from Washington and Oregon, including fossil teeth (Kohn and Fremd, 2007), paleosol carbonates (Retallack et al., 2004; Takeuchi et al., 2010; Lechler et al., 2018), smectites (Takeuchi and Larson, 2005), and carbonate concretions (Methner et al., 2016) (Figure 1, Supplementary Table S1).

The late Cenozoic topographic history of the Cascades is disputed. Of the publications compiled for this study, Takeuchi and Larson (2005), Takeuchi et al., (2010) and Methner et al. (2016) propose most uplift occurred in the Neogene. Kohn and Fremd (2007) present data that may reflect near modern elevations in the Cascades by the late Oligocene, with an additional $\sim 800 \mathrm{~m}$ of uplift in the last $\sim 6 \mathrm{Ma}$. This interpretation is consistent with an interpretation of volcanic glass data (Bershaw et al., 2019). Retallack (2004a) shows that late Oligocene paleosols track Milankovitch cycles, but also suggests that Cascade uplift and rainshadow development play roles in longer-term trends (Retallack, 2004b). Lastly, dating of igneous rocks and thermochronologic data suggest that the uplift history of the Cascades varies across space and time (Robinson et al., 1984; Verplanck and Duncan, 1987; Conrey et al., 2002; Pesek et al., 2020).
A

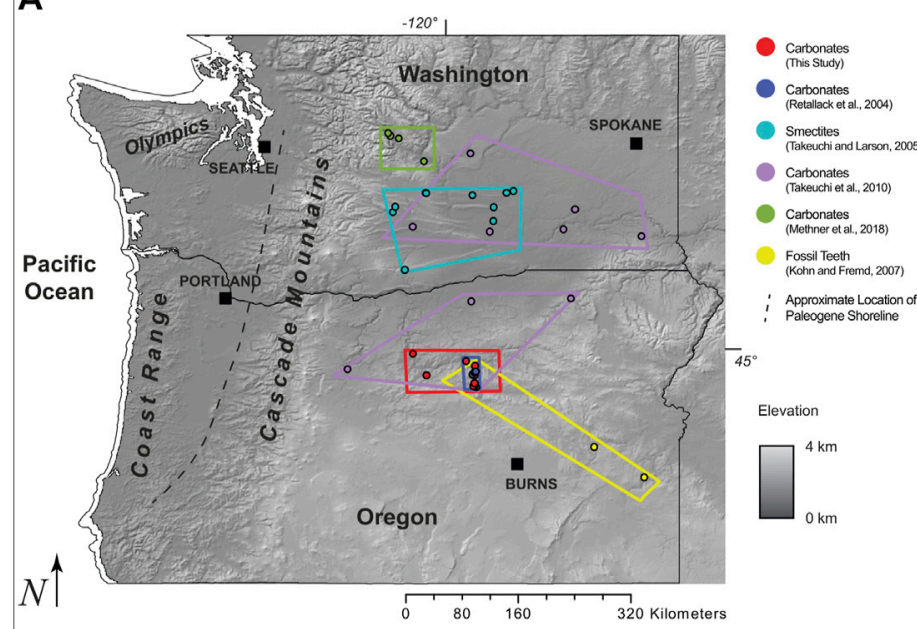

B

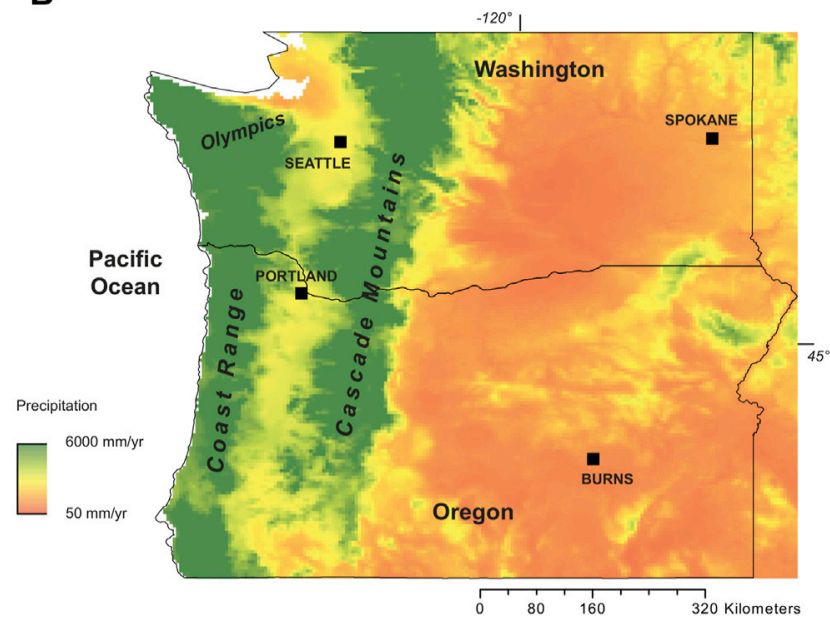

FIGURE 1 | (A) Location map showing the extent of new data (red) and published datasets throughout the Pacific Northwest. Elevation is shown as greyscale in km. Dashed line shows the inferred Paleogene shoreline prior to the emergence of the Oregon Coast Range based on paleogeographic maps by Orr and Orr (1999) and references therein. Digital Elevation Model (DEM) is based on the United States. Geological Survey Global 30 Arc-Second GTOPO30 (https://doi.org/10.5066/ F7DF6PQS). (B) Map showing annual precipitation amount, averaged from 1981-2010 across the Pacific Northwest. Data Source: PRISM Climate Group (http:// prism.oregonstate.edu). 


\section{METHODS}

Paleosol carbonates throughout the John Day Formation of known age ( 30-16 Ma) were sampled from locations described in Retallack et al., (1999) (Figure 1B, Supplementary Figure S3). $\sim 100 \mathrm{~g}$ of sample was collected after removing the upper $30 \mathrm{~cm}$ of outcrop to reduce the influence of evaporation. Diagenetically altered samples, identified in the field by spar, calcite veins, and oxidation, were avoided (e.g. Bershaw et al., 2012).

Samples were crushed to powder and reacted with $30 \% \mathrm{H}_{2} \mathrm{O}_{2}$ to remove organics. Analyses were carried out at the Iowa State University Stable Isotope Lab (SIL) on a ThermoFinnigan Delta Plus XL mass spectrometer in continuous-flow mode via Thermo GasBench II with a CombiPal autosampler. The long-term precision of the mass spectrometer for $\delta^{18} \mathrm{O}$ is $0.06 \%$. Isotopic results are reported in standard delta notation $\left(\delta^{18} \mathrm{O}\right)$ relative to Vienna Standard Mean Ocean Water (VSMOW) (Supplementary Table S1).

To compare different proxy material, we estimate the stable isotopic composition of meteoric water using empirically derived fractionation factors (O’Neil et al., 1969; Yeh and Savin, 1977). To reduce interpretive bias, we apply a consistent standard for estimating the temperature of carbonate formation using ancient flora (Wolfe, 1994, Supplementary Table S1) or $\Delta 47$ temperatures when available. Our estimates are consistent with published water values where available. Fossil tooth data was averaged over the length of teeth and converted to water using an empirical relationship between environmental water and tooth chemistry (Kohn and Fremd, 2007). Differences between proxy data may exist that are related to unique conditions of mineral formation, such as the season or temperature of precipitation (Quade et al., 2007; Breecker et al., 2009).

We collected and analyzed 20 carbonate samples in central Oregon which we report here (Supplementary Table S1). Sample ages were determined by comparing stratigraphic position with published ages based on radiometric dating of tuff beds (Retallack et al., 1999; Retallack, 2004a). Exceptions are COS197 and COS197b, which are dated based on their position atop the Dayville Basalt (16.1 Ma) and below the Mascall Tuff Bed (15.2 Ma) (Prothero et al., 2006; Bestland et al., 2008; Drewicz and Kohn, 2018).

\section{RESULTS}

The average $\delta^{18} \mathrm{O}$ value of our data is $-11.2 \%$ with a range from -14.6 to $-7.0 \%$. This is $1.6 \%$ more positive than the average of modern meteoric water in the lee (east) of the Oregon Cascade Mountains $(-12.8 \%)$, but within the range $(-16.2$ to $-8.8 \%$ o (Supplementary Table S2).

We combine our results with published data throughout the region, including 172 paleosol carbonates from Washington and Oregon (Takeuchi et al., 2010), 367 paleosol carbonates from Oregon (Retallack et al., 2004), 22 smectites from Washington (Takeuchi and Larson, 2005), 243 fossil teeth from Oregon (Kohn and Fremd, 2007), 31 modern carbonates from Washington
(Lechler et al., 2018), and 119 carbonate concretions from Washington (Methner et al., 2016) (Figures 1 B2 and Supplementary Table S1). Published modern stream water $\delta^{18} \mathrm{O}$ values from Washington and Oregon are reported for comparison (Supplementary Table S2), though they integrate less time than mineral proxy material so are inherently more variable. Ages of Eocene carbonates in WA, United States represent maximum ages, as there is uncertainty on the timing of potential diagenesis (Methner et al., 2016).

Together, these data do not show significant relationships between isotopic composition and latitude, longitude, elevation, or age ( $R^{2}$ of $0.15,0.00,0.22$, and 0.13 , respectively). We separate datasets by state, as this provides a convenient latitudinal break between the northern Cascades of Washington and central Cascades of Oregon. In Washington, the average paleowater $\delta^{18} \mathrm{O}$ for all samples is $-14.3 \pm 2.8 \%$ ( $\left.1 \sigma \mathrm{SD}\right)$ and range from -18.0 to $-6.8 \%$. There is a weak, negative correlation between age and $\delta^{18} \mathrm{O}$ in samples from Washington, with an $R^{2}$ of 0.40 . The average $\delta^{18} \mathrm{O}$ in Oregon is $-11.9 \pm 2.1 \%$ ( $\left.1 \sigma \mathrm{SD}\right), \sim 2.4 \%$ o more positive than Washington, with a range of -15.8 to $-8.4 \%$. Oregon carbonates demonstrate negligible correlation between age and $\delta^{18} \mathrm{O}\left(R^{2}\right.$ of 0.03$)$. Sample $\delta^{18} \mathrm{O}$ values from individual studies are averaged within 2.5 million-year bins to emphasize trends in climate and topography across geologic time (Figure 2).

\section{DISCUSSION}

\section{Carbonates as a Proxy for Ancient Meteoric Water}

Before interpreting geologic and climatic trends, we assess whether proxies accurately reflect meteoric water at the time of deposition. Several paleosol carbonate samples from central Oregon likely experienced some form of alteration which may change primary carbonate $\delta^{18} \mathrm{O}$ values, due to different formation water and/or temperatures of mineral precipitation. One Oligocene sample from our dataset (JDRL02, Figure A-6 of Supplementary Figure S3) has an anomalously low $\delta^{18} \mathrm{O}$ value $(-18.2 \%$ ) (open red circle in Figure 2A). This sample is purple in hue and only weakly calcareous, so it is likely that it underwent oxidation weathering sometime after deposition, potentially obfuscating the isotopic signal with oxide minerals (Hoefs, 2009). In addition, pedogenic carbonate $\delta^{18} \mathrm{O}$ values from Retallack et al. (2004) across the late Oligocene (blue curve in Figure 2A) plot more negative $(\sim 5 \%)$ than roughly contemporaneous fossil teeth and paleosols. This difference may be explained by higher temperatures of carbonate precipitation. The Turtle Cove Member, which makes up samples $24 \mathrm{Ma}$ and older (Retallack et al., 2004), contains significant amounts of celadonite, which is an alteration product forming between $27-100^{\circ} \mathrm{C}$ (Weaver, 1989; Lander and Hay, 1993). Hay (1963) provides a narrower range of water temperatures for this interaction $\left(27-55^{\circ} \mathrm{C}\right)$ and an age estimate of when this occurred $(24 \pm 2 \mathrm{Ma})$. If the temperature of carbonate precipitation was $>50^{\circ} \mathrm{C}$, as observed in Paleogene carbonates from Washington (Methner et al., 2016), this would cause a decrease in $\delta^{18} \mathrm{O}$ of over $5 \%$ (Kim and O'Neil, 
1997), explaining anomalously low $\delta^{18} \mathrm{O}$ values (blue curve in Figure 2) relative to contemporaneous proxy data.

\section{Regional Synthesis: Oregon}

Previous studies have proposed various interpretations of Cenozoic mountain uplift and climate change in Oregon based on proxy data, including late Neogene uplift of the Cascade Mountains (Takeuchi and Larson, 2005; Takeuchi et al., 2010), contrasted by interpretations of high topography by late Oligocene time (Kohn and Fremd, 2007; Bershaw et al., 2020), in addition to the assertion that global climate change exerts a first-order control on isotopic records in Oregon (Retallack et al., 2004). In our regional synthesis, we focus on tectonic (millionyear scale) forcing of isotopic data and do not consider carbonates from Retallack et al. (2004) (blue curve in Figure 2A), or our sample JDRL02 (open red circle in Figure 2A), whose temperature of formation may be higher than we assumed.

Our new time-averaged carbonate data is within the range of other water proxy data in Oregon. The isotopic variability in contemporaneous paleowater proxy material is similar to that observed in modern soils and teeth (grey vertical bar in Figure 2A) and smaller than modern meteoric water (black vertical bar in Figure 2A). Our paleosol carbonate data and fossil tooth data of Kohn and Fremd (2007) (red and yellow curve in Figure 2A) are within the wide range of modern meteoric water (dark vertical bar in Figure 2A) in the Oregon Cascade rainshadow, supporting the interpretation that some topography, possibly similar to modern $(\sim 1.5 \mathrm{~km})$, existed by the late Oligocene. Additionally, modern coastal water $\delta^{18} \mathrm{O}$ values (average $-6.8 \%$, Bershaw et al., 2020) are 5.3\% more positive than the average $\delta^{18} \mathrm{O}$ of Paleogene, non-diagenetic carbonate in Oregon, which average $-12.1 \%$ o $(n=5)$. Our interpretation of near modern topography in the Oregon Cascades by Oligocene time is consistent with evidence of significant volcanism at that time (Verplanck and Duncan, 1987; Priest, 1990; Taylor, 1990) and volcanic glass $\delta D$ data across the range (Bershaw et al., 2019).

Our new paleosol carbonate $\delta^{18} \mathrm{O}$ values decrease by $\sim 2.5 \%$ from 29 to $16 \mathrm{Ma}$. However, taken as a whole, our data is within the range of fossil teeth and previously published paleosol carbonate $\delta^{18} \mathrm{O}$ results whose average stays relatively constant across the Oligocene and early Miocene, suggesting Cascade Mountain topography was relatively stable during this time. Variation in values (particularly high among teeth) may reflect Milankovitch cycles and/or spatial variability among sample locations within the study area (Figure 1). This could reflect local topography and associated microclimates (Retallack, 2004b; Kukla et al., 2021 this volume), as observed in modern meteoric water across the same spatial extent (Bershaw et al., 2020).

Fossil tooth (Kohn and Fremd, 2007) and paleosol carbonate (Takeuchi et al., 2010) $\delta^{18} \mathrm{O}$ values from the late Miocene and Pliocene are $2-3 \%$ more positive than modern carbonates and teeth (Figure 2A) in central Oregon. This is likely not caused by global cooling at this time, as northern hemisphere ice sheet expansion resulted in a $\sim 1.5 \%$ increase in oceanic $\delta^{18} \mathrm{O}$, whereas our data reflect a decrease in $\delta^{18} \mathrm{O}$ (Zachos et al., 2001). Instead, we suggest this negative shift in isotopic composition since the late Miocene may reflect the westward migration $(>100 \mathrm{~km})$ of the Oregon coast, driven by the Neogene emergence of a subaerial Oregon Coast Range (Figure 1B). A drop in $\delta^{18} \mathrm{O}$ values would be expected as the distance to the Pacific Ocean increased and a subaerial Coast Range created a modest moisture barrier, further depleting ${ }^{18} \mathrm{O}$ in vapor. Emergence of the Coast Range at this time is independently constrained by an analysis of the Portland Basin, which shows a significant decrease in accommodation space
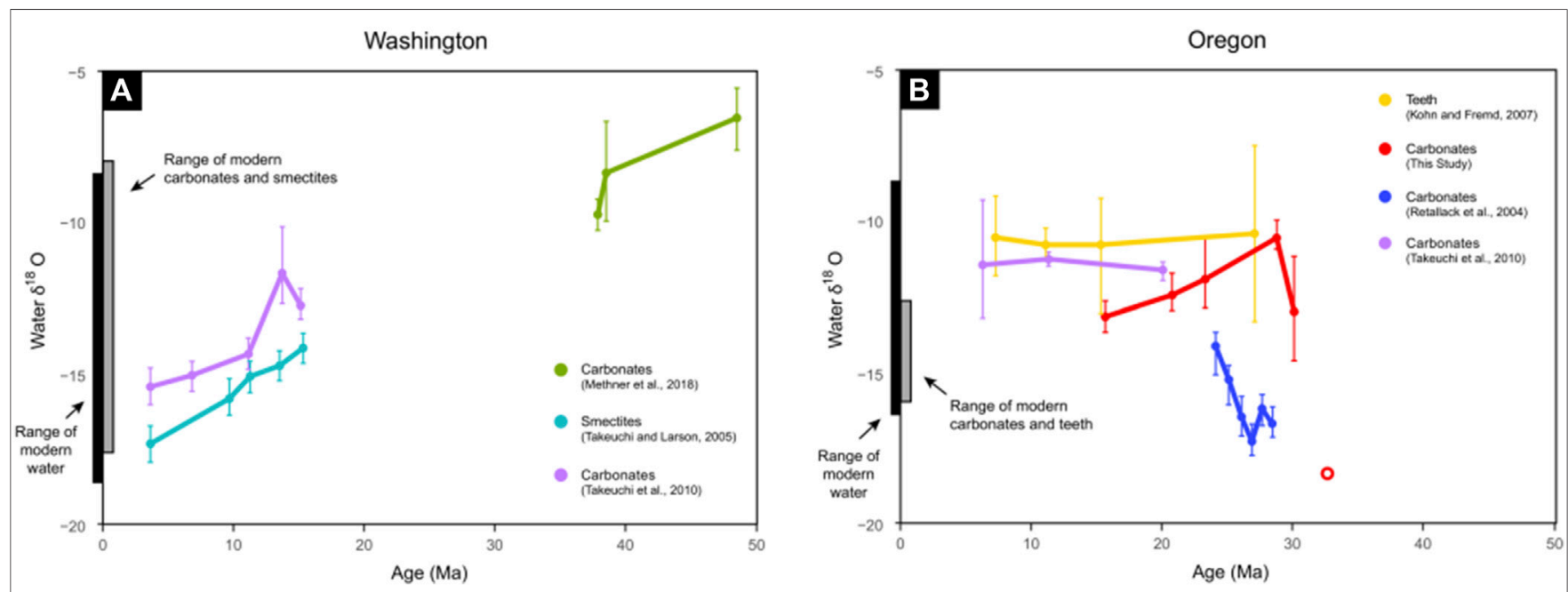

FIGURE 2 | Plots showing temporal variations in meteoric water based on $\delta^{18} \mathrm{O}$ values of carbonates, smectites, and fossil teeth for central Washington at $\sim 47$ latitude (A) and central Oregon at $\sim 5$ latitude (B), both in the lee (east side) of the Cascade Mountains. Sample $\delta^{18} \mathrm{O}$ values are averaged within 2.5 million-year windows (shown as points) to emphasize trends across geologic time. Uncertainty bars represent the range of $\delta^{18} \mathrm{O}$ values found within each time-window. Samples are grouped (color-coded) by publication and sample type. The range of modern meteoric water $\delta^{18} \mathrm{O}$ east of the Cascade Mountains is shown (black bar) for both Washington and Oregon based on published stream data (Table S2). Ranges in published modern carbonates east of the Cascade Mountains (Takeuchi et al., 2010; Lechler et al., 2018 and this study), smectites (Takeuchi and Larson, 2005), and mammal teeth (Kohn and Fremd, 2007) $\delta^{18} \mathrm{O}$ data (Supplementary Table S1) are also shown for each state (gray bar). The open red circle (Oregon) represents sample JDRL_02, interpreted to be diagenetic carbonate. 
sometime after the eruption of the CRBG in the mid-Miocene and coeval migration of basin depocenters eastward (Scanlon et al., 2019 in press). Modern coastal meteoric water $\delta^{18} \mathrm{O}$ values are $\sim 2.4 \%$ higher than those in the western foothills of the Cascade Mountains (Bershaw et al., 2020), where the coastline was prior to Coast Range uplift. This suggests that uplift of the Coast Range could account for the discrepancy between late Miocene and modern water proxy data.

\section{Regional Synthesis: Washington}

Estimated meteoric water $\delta^{18} \mathrm{O}$ values from Eocene carbonates in Washington (Methner et al., 2016) are relatively positive (average $-8.8 \%$ o compared to both modern water (average $-14.6 \%$ ) and modern carbonates and smectites nearby (average -14.0\%o) (Figure 2B and Supplementary Table S1). Instead, they are similar to the isotopic composition of modern stream water at low elevations on the west side of the Olympics $(-7.1 \%$ o) and Cascades in WA, United States (-9.1\%) (Bershaw et al., 2020), suggesting the northern Cascades Mountains were not a significant topographic barrier to westerly derived moisture at that time.

Eocene paleowater $\delta^{18} \mathrm{O}$ values are also significantly more positive than Miocene and Pliocene smectite and paleosols (Figure 2B), resulting in a progressive trend towards more negative $\delta^{18} \mathrm{O}$ values across the Cenozoic. This is not likely the result of global cooling, as temperature change is moderated by an increase in oceanic $\delta^{18} \mathrm{O}$ of $\sim 1.8 \%$ from the late Eocene to Miocene (Zachos et al., 2001). We hypothesize that the northern Cascades in Washington have undergone progressive topographic uplift since the Paleogene. At what point uplift resulted in a rainshadow in central WA, United States is less clear, though paleofloral data from Idaho and paleosol carbonate $\delta^{13} \mathrm{C}$ data from Washington suggest arid conditions similar to modern were not established until the late Miocene or Pliocene (Takeuchi et al., 2010; Mustoe and Leopold, 2013). Progressive uplift through much of the Cenozoic is consistent with evidence that the northern Cascades were an active volcanic arc in the Paleogene (Tabor et al., 1984) and thermochronology that shows slow uplift of the Washington Cascades $(<0.25 \mathrm{~km} / \mathrm{m} . \mathrm{y}$.) from the Eocene to the late Miocene (Reiners et al., 2002; Pesek et al., 2020), with ongoing uplift today (Wells and McCaffrey, 2013).

\section{Polygenetic History of Topography Across the Pacific Northwest}

Our synthesis of water proxy datasets shows a polygenetic uplift history for the Cascade Mountains along strike. Oregon and Washington carbonates show distinct temporal trends, with differences as large as $\sim 5 \%$ o across the late Miocene, where Oregon paleowaters are more enriched than contemporaneous water in Washington (Figure 2). These spatial discrepancies support our assertion that global climate change is not the primary forcing mechanism behind isotopic change in the Pacific Northwest on tectonic (million year) scales. Instead, isotopic proxy records suggest that the Northern Cascades in
Washington were not a significant barrier to westerly airflow in the Eocene, but experienced progressive topographic uplift from the Paleogene to now, while the Cascades in Oregon formed a topographic barrier by the late Oligocene, but remained relatively unchanged into the Neogene. This interpretation is consistent with the tectonic framework of the region since midMiocene time, where east-west extension (subsidence) has developed in the Oregon Cascades (Conrey et al., 1997; Guffanti and Weaver, 1988) while uplift of the northern Cascades is due to subduction-related rigid block rotation (Figure 4 from Wells et al., 1998), delamination (Reiners et al., 2002), and/or erosional denudation (Enkelmann et al., 2015). Our interpretation of polygenetic uplift across the Oregon and Washington Cascades in consistent with volcanic glass $\delta$ D values (Bershaw et al., 2019) and thermochronometry, which shows significant geographic variation in exhumation timing (Pesek et al., 2020), as opposed to contemporaneous, wholesale uplift of the entire Cascade Mountain chain.

Additionally, we hypothesize that the subaerial emergence of the Coast Range in Oregon and westward migration of the coastline (Scanlon et al., 2019 in press) caused a modest depletion in proxy material $\delta^{18} \mathrm{O}$ values that is not apparent in Washington proxy data, where the coastline remains at the base of the northern Cascades and the Puget Lowland remains connected to the ocean today. The migration of the coastline west and drying of the Willamette Valley (forearc) in the late Miocene coincides with aridification of central Washington and Idaho (Takeuchi et al., 2010; Mustoe and Leopold, 2013). We speculate that this shift in paleoclimate may reflect an increase in continentality (distance from oceanic water source) as opposed to wholesale Cascade Mountain uplift at that time.

\section{CONCLUSION}

We present new pedogenic carbonate $\delta^{18} \mathrm{O}$ data from central Oregon and synthesize this with published water proxy data from across the Pacific Northwest. We interpret a polygenetic history of Cascade Mountain topographic uplift along-strike, characterized by: 1) Progressive uplift of the Washington Cascades through the Cenozoic due long-term arc rotation and shortening against a Canadian buttress, and 2) Uplift of the Oregon Cascades to similar-to-modern elevations by the late Oligocene, followed by topographic stagnation as extension developed into Neogene time. Since the Miocene, meteoric water $\delta^{18} \mathrm{O}$ values have decreased in Oregon, possibly due to emergence of the Coast Range and westward migration of the coastline. Isotopic trends could also be influenced by changes in seasonality, the isotopic composition of the Pacific Ocean, and Blue or Klamath Mountain topography. Lastly, variability in $\delta^{18} \mathrm{O}$ values of proxy materials at any given time is likely forced by Milankovitch cycles, local topography (and associated microclimates), and volatility inherent in arid environments, where evaporation of surface water can be significant. 


\section{DATA AVAILABILITY STATEMENT}

The original contributions presented in the study are included in the article/Supplementary Material, further inquiries can be directed to the corresponding authors.

\section{AUTHOR CONTRIBUTIONS}

There are two authors who contributed to this manuscript. AM (corresponding author) contributed to collecting and analyzing samples, writing the manuscript, interpreting the results and compiling figures and tables. JB contributed to collecting samples, writing the manuscript, interpreting results, and compiling figures. Both authors agree to be accountable for the content of the work.

\section{REFERENCES}

Beeson, M. H., Tolan, T. L., and Anderson, J. L. (1989). “The Columbia River Basalt Group in western Oregon; geologic structures and other factors that controlled flow emplacement patterns," in Volancism and tectonism in the Columbia River flood-basalt province: Geological Society of America Special Paper. Editors S. P. Reidel and P. R. Hooper (Boulder, Colorado: Geological Society of America), 239, 223-246.

Bershaw, J., Garzione, C. N., Schoenbohm, L., Gehrels, G., and Tao, L. (2012). Cenozoic evolution of the Pamir plateau based on stratigraphy, zircon provenance, and stable isotopes of foreland basin sediments at Oytag (Wuyitake) in the Tarim Basin (west China). J. Asian Earth Sci. 44, 136-148. doi:10.1016/j.jseaes.2011.04.020

Bershaw, J., Cassel, E. J., Carlson, T. B., Streig, A. R., and Streck, M. J. (2019). Volcanic glass as a proxy for Cenozoic elevation and climate in the Cascade Mountains, Oregon, USA. J. Volcanol. Geotherm. Res. 381, 157-167. doi:10. 1016/j.jvolgeores.2019.05.021

Bershaw, J., Hansen, D. D., and Schauer, A. J. (2020). Deuterium excess and 17Oexcess variability in meteoric water across the Pacific Northwest, USA. Tellus B: Chem. Phys. Meteorol. 72 (1), 1-17. doi:10.1080/16000889.2020.1773722

Bestland, E. A., Forbes, M. S., Krull, E. S., Retallack, G. J., and Fremd, T. (2008). Stratigraphy, paleopedology, and geochemistry of the middle Miocene Mascall Formation (type area, central Oregon, USA). PaleoBios. 28 (2), 41-61.

Bestland, E. A., Hammond, P. E., Blackwell, D. L. S., Kays, M. A., Retallack, G. J., and Stimac, J. (1999). Geologic framework of the clarno unit, John day fossil beds national monument, central Oregon. Oreg. Geol. 61 (1), 3-19.

Breecker, D. O., Sharp, Z. D., and McFadden, L. D. (2009). Seasonal bias in the formation and stable isotopic composition of pedogenic carbonate in modern soils from central New Mexico, USA. Geol. Soc. Am. Bull. 121, 630-640.

Cerling, T. E., and Quade, J. (1993). Climate change in continental isotopic records. Geophys. Monogr. 78, 217-231.

Conrey, R. M., Sherrod, D. R., Hooper, P. R., and Swanson, D. A. (1997). Diverse primitive magmas in the Cascade arc, northern Oregon and southern Washington. Can. Mineral. 35 (2), 367-396.

Conrey, R. M., Taylor, E. M., Donnelly-Nolan, J. M., and Sherrod, D. R. (2002). "Northcentral Oregon Cascades: exploring petrologic and tectonic intimacy in a propagating intra-arc rift," in Field guide geologic process in cascadia; 98th annual meeting of the cordilleran section of the geological society of America. Editor G. W. Moore (Oregon: Oregon Department of Geology and Mineral Industries), 36, 47-90.

Currie, B. S., Polissar, P. J., Rowley, D. B., Ingalls, M., Li, S., Olack, G., et al. (2016). Multiproxy paleoaltimetry of the late Oligocene-Pliocene Oiyug basin, southern Tibet. Am. J. Sci. 316 (5), 401-436. doi:10.2475/05.2016.01

Drewicz, A. E., and Kohn, M. J. (2018). Stable isotopes in large herbivore tooth enamel capture a mid-Miocene precipitation spike in the interior Pacific Northwest. Palaeogeogr. Palaeoclimatol. Palaeoecol. 495, 1-12. doi:10.1016/j.palaeo.2017.11.022

\section{ACKNOWLEDGMENTS}

Samples were collected at John Day Fossil Beds National Monument under Permit JODA-2019-SCI-0009. The authors would like to thank Dr. Nicholas Famoso, The National Park Service, and Patrick Gamman for facilitating sample collection and providing insight. Publication of this article in an open access journal was funded by the Portland State University Library's Open Access Fund.

\section{SUPPLEMENTARY MATERIAL}

The Supplementary Material for this article can be found online at: https:/www.frontiersin.org/articles/10.3389/feart.2021.624961/ full\#supplementary-material.

du Bray, E., and John, D. A. (2011). Petrologic, tectonic, and metallogenic evolution of the Ancestral Cascades magmatic arc, Washington, Oregon, and northern California. Geosphere 7 (5), 1102-1133. doi:10.1130/ges00669.1

Enkelmann, E., Ehlers, T. A., Merli, G., and Methner, K. (2015). Thermal and exhumation history of the Eocene chumstick basin, Washington state, USA. Tectonics 34 (5), 951-969. doi:10.1002/2014tc003767

Garzione, C. N., Quade, J., DeCelles, P. G., and English, N. B. (2000). Predicting paleoelevation of Tibet and the Himalaya from $\delta 18 \mathrm{O}$ vs. altitude gradients in meteoric water across the Nepal Himalaya. Earth Planet. Sci. Lett. 183 (1-2), 215-229. doi:10.1016/s0012-821x(00)00252-1

Gébelin, A., Mulch, A., Teyssier, C., Page Chamberlain, C., and Heizler, M. (2012). Coupled basin-detachment systems as paleoaltimetry archives of the western North American Cordillera. Earth Planet. Sci. Lett. 335-336, 36-47. doi:10. 1016/j.epsl.2012.04.029

Guffanti, M., and Weaver, C. S. (1988). Distribution of late Cenozoic volcanic vents in the Cascade Range: volcanic arc segmentation and regional tectonic considerations. J. Geophys. Res. 93 (B6), 6513-6529. doi:10.1029/ jb093ib06p06513

Hay, R. L. (1963). Stratigraphy and zeolitic diagenesis of the john day formation of Oregon. California: University of California Press

Hayes, J. M. (2001). Fractionation of carbon and hydrogen isotopes in biosynthetic processes. Rev. Mineral. Geochem. 43 (1), 225-277. doi:10.2138/gsrmg.43.1.225 Hoefs, J. (2009). Stable isotope geochemistry. Berlin: Springer, 285

Kim, S. T., and O'Neil, J. R. (1997). Equilibrium and nonequilibrium oxygen isotope effects in synthetic carbonates. Geochim. Cosmochim. Acta 61 (16), 3461-3475. doi:10.1016/s0016-7037(97)00169-5

Kohn, M. J., and Fremd, T. J. (2007). Tectonic controls on isotope compositions and species diversification, John Day Basin, central Oregon. PaleoBios. 27 (2), 48-61.

Kohn, M. J., and Law, J. M. (2006). Stable isotope chemistry of fossil bone as a new paleoclimate indicator. Geochim. Cosmochim. Acta. 70 (4), 931-946. doi:10. 1016/j.gca.2005.10.023

Kohn, M. J., Miselis, J. L., and Fremd, T. J. (2002). Oxygen isotope evidence for progressive uplift of the Cascade Range, Oregon. Earth Planet. Sci. Lett. 204 (1-2), 151-165. doi:10.1016/s0012-821x(02)00961-5

Kukla, T., Ibarra, D. E., Caves, J. K., Gooley, J. T., Mullins, C. E., Kramer, S., et al. (2021). High-resolution stable isotope paleotopography of the John day region, Oregon, USA. Front. Earth Sci. 9, 30. doi:10.3389/feart.2021. 635181

Lander, R. H., and Hay, R. L. (1993). Hydrogeologic control on zeolitic diagenesis of the White River sequence. Geol. Soc. Am. Bull. 105 (3), 361-376. doi:10.1130/ 0016-7606(1993)105<0361:hcozdo>2.3.co;2

Lechler, A. R., Huntington, K. W., Breecker, D. O., Sweeney, M. R., and Schauer, A J. (2018). Loess-paleosol carbonate clumped isotope record of late PleistoceneHolocene climate change in the Palouse region, Washington State, USA. Quat. Res. 90 (2), 331-347. doi:10.1017/qua.2018.47 
Mack, G. H., Cole, D. R., and Treviño, L. (2000). The distribution and discrimination of shallow, authigenic carbonate in the Pliocene-Pleistocene Palomas Basin, southern Rio Grande rift. Geol. Soc. Am. Bull. 112 (5), 643-656. doi:10.1130/0016-7606(2000)112<643:tdados >2.0.co;2

Methner, K., Fiebig, J., Wacker, P., Umhoefer, J., Chamberlain, C. P., and Mulch, L. A. (2016). Eocene-Oligocene proto-Cascades topography revealed by clumped $(\triangle 47)$ and oxygen isotope $(\delta 18 \mathrm{O})$ geochemistry (Chumstick Basin, WA, USA). Tectonics 35, 546-564.

Mulch, A., and Chamberlain, C. P. (2007). Stable isotope paleoaltimetry in orogenic belts the silicate record in surface and crustal geological archives. Rev. Mineral. Geochem. 66 (1), 89-118. doi:10.2138/rmg.2007.66.4

Mustoe, G. E., and Leopold, E. B. (2014). Paleobotanical evidence for the postMiocene uplift of the Cascade Range. Can. J. Earth Sci. 51, 809-824.

O’Neil, J. R., Clayton, R. N., and Mayeda, T. K. (1969). Oxygen isotope fractionation in divalent metal carbonates. J. Chem. Phys. 51 (12), 5547-5558. doi:10.1063/1.1671982

Orr, E. L., and Orr, W. N. (1999). Geology of Oregon. 5th Edition. Dubuque, Iowa: Kendall Hunt Publishing Company

Pesek, M. E., Perez, N. D., Meigs, A., Rowden, C. C., and Giles, S. M. (2020). Exhumation timing in the Oregon Cascade Range decoupled from deformation, magmatic, and climate patterns. Tectonics 39 (9), e2020TC006078. doi:10.1029/2020tc006078

Priest, G. R. (1990). Volcanic and tectonic evolution of the Cascade volcanic arc, central Oregon. J. Geophys. Res. 95 (B12), 19583-19599. doi:10.1029/ jb095ib12p19583

Prothero, D. R., Draus, E., and Foss, S. E. (2006). Magnetic stratigraphy of the lower portion of the middle Miocene Mascall Formation, central Oregon. PaleoBios 26 (1), 37-42.

Quade, J., Garzione, C., and Eiler, J. (2007). Paleoelevation reconstruction using pedogenic carbonates. Rev. Mineral. Geochem. 66 (1), 53-87. doi:10.2138/rmg. 2007.66.3

Reidel, S. P., Camp, V. E., Tolan, T. L., and Martin, B. S. (2013). The Columbia River flood basalt province: stratigraphy, areal extent, volume, and physical volcanology. Geol. Soc. Am. Spec. Pap. 497, 1-43. doi:10.1130/2013.2497(1)

Reiners, P. W., Ehlers, T. A., Garver, J. I., Mitchell, S. G., Montgomery, D. R., Vance, J. A., et al. (2002). Late Miocene exhumation and uplift of the Washington cascade range. Geology 30 (9), 767-770. doi:10.1130/00917613(2002)030<0767:Imeauo >2.0.co;2

Retallack, G. J. (2004a). Late Oligocene bunch grassland and early Miocene sod grassland paleosols from central Oregon, USA. Palaeogeogr. Palaeoclimatol. Palaeoecol. 207 (3-4), 203-237. doi:10.1016/j.palaeo.2003.09.027

Retallack, G. J. (2004b). Late Miocene climate and life on land in Oregon within a context of Neogene global change. Palaeogeogr. Palaeoclimatol. Palaeoecol. 214 (1-2), 97-123. doi:10.1016/s0031-0182(04)00394-3

Retallack, G. J., Bestland, E. A., and Fremd, T. J. (1999). Eocene and Oligocene paleosols of central Oregon. Boulder, Colorado: Geological Society of America, 344

Retallack, G. J., Tanaka, S., and Tate, T. (2002). Late Miocene advent of tall grassland paleosols in Oregon. Palaeogeogr. Palaeoclimatol. Palaeoecol. 183 (3-4), 329-354. doi:10.1016/s0031-0182(02)00250-x

Retallack, G. J., Wynn, J. G., and Fremd, T. J. (2004). Glacial-interglacial-scale paleoclimatic change without large ice sheets in the Oligocene of central Oregon. Geology 32 (4), 297-300. doi:10.1130/g20247.1

Robinson, P. T., Brem, G. F., and McKee, E. H. (1984). John Day Formation of Oregon: a distal record of early Cascade volcanism. Geology 12 (4), 229-232. doi:10.1130/0091-7613(1984)12<229:jdfooa >2.0.co;2

Robinson, P. T., Walker, G. W., and McKee, E. H. (1990). "Eocene (?), Oligocene, and lower Miocene rocks of the blue mountains region," in Geology of the blue mountains region of Oregon, Idaho, and Washington: cenozoic geology of the blue mountains region. Editor G. W. Walker (Reston, Virginia: US Geological Survey), 29-62.

Rowley, D. B., and Garzione, C. N. (2007). Stable isotope-based paleoaltimetry. Annu. Rev. Earth Planet. Sci. 35, 463-508. doi:10.1146/annurev.earth.35. 031306.140155

Sanyal, P., Bhattacharya, S. K., and Prasad, M. (2005). Chemical diagenesis of Siwalik sandstone: isotopic and mineralogical proxies from Surai Khola section, Nepal. Sediment. Geol. 180 (1-2), 57-74. doi:10.1016/j.sedgeo.2005.06.005

Savin, S. M. (1982). "Stable isotopes in climatic reconstructions," in Climate and Earth history. Washington, DC: Natl. Acad. Press, 164-171.
Scanlon, D. P., Bershaw, J., Wells, R. E., and Streig, A. R. (2019). The spatial and temporal evolution of the Portland and tualatin forearc basins, Oregon, USA. MS Thesis. Oregon: Portland State University.

Sherrod, D. R., and Smith, J. G. (2000). Geologic map of upper Eocene to Holocene volcanic and related rocks of the Cascade Range, Oregon. Washington, DC: US Geological Survey, 17

Smith, G. A., Snee, L. W., and Taylor, E. M. (1987). Stratigraphic, sedimentologic, and petrologic record of late Miocene subsidence of the central Oregon High Cascades. Geology 15 (5), 389-392. doi:10.1130/0091-7613(1987)15<389: ssapro $>2.0 . \mathrm{co} ; 2$

Snavely, P. D., MacLeod, N. S., and Wagner, H. C. (1973). Miocene tholeiitic basalts of coastal Oregon and Washington and their relations to coeval basalts of the Columbia Plateau. Geol. Soc. Am. Bull. 84 (2), 387-424. doi:10.1130/00167606(1973)84<387:mtboco >2.0.co;2

Streck, M. J., and Grunder, A. L. (1995). Crystallization and welding variations in a widespread ignimbrite sheet; the Rattlesnake Tuff, eastern Oregon, USA. Bull. Volcanol. 57 (3), 151-169. doi:10.1007/s004450050086

Tabor, R. W., Frizzell, V. A., Vance, J. A., and Naeser, C. W. (1984). Ages and stratigraphy of lower and middle Tertiary sedimentary and volcanic rocks of the central Cascades, Washington: application to the tectonic history of the Straight Creek fault. Geol. Soc. Am. Bull. 95 (1), 26-44. doi:10.1130/0016-7606(1984) $95<26$ :aasola $>2.0$. co; 2

Takeuchi, A., Hren, M. T., Smith, S. V., Chamberlain, C. P., and Larson, P. B. (2010). Pedogenic carbonate carbon isotopic constraints on paleoprecipitation: evolution of desert in the Pacific Northwest, USA, in response to topographic development of the Cascade Range. Chem. Geol. 277 (3-4), 323-335. doi:10. 1016/j.chemgeo.2010.08.015

Takeuchi, A., and Larson, P. B. (2005). Oxygen isotope evidence for the late Cenozoic development of an orographic rain shadow in eastern Washington, USA. Geology 33 (4), 313-316. doi:10.1130/g21335.1

Taylor, E. M. (1990). Volcanic history and tectonic development of the Central High Cascade Range, Oregon. J. Geophys. Res. 95 (B12), 19611-19622. doi:10. 1029/jb095ib12p19611

Verplanck, E. P., and Duncan, R. A. (1987). Temporal variations in plate convergence and eruption rates in the Western Cascades, Oregon. Tectonics 6 (2), 197-209. doi:10.1029/tc006i002p00197

Weaver, C. E. (1989). Clays, muds, and shales. Amsterdam, NL: Elsevier

Wells, R., Bukry, D., Friedman, R., Pyle, D., Duncan, R., Haeussler, P., et al. (2014). Geologic history of Siletzia, a large igneous province in the Oregon and Washington Coast Range: correlation to the geomagnetic polarity time scale and implications for a long-lived yellowstone hotspot. Geosphere 10 (4), 692-719. doi:10.1130/ges01018.1

Wells, R. E., and McCaffrey, R. (2013). Steady rotation of the Cascade arc. Geology 41 (9), 1027-1030. doi:10.1130/g34514.1

Wells, R. E., Weaver, C. S., and Blakely, R. J. (1998). Fore-arc migration in Cascadia and its neotectonic significance. Geology 26 (8), 759-762. doi:10.1130/00917613(1998)026<0759:famica>2.3.co;2

Wolfe, J. A. (1994). Tertiary climatic changes at middle latitudes of western North America. Palaeogeogr. Palaeoclimatol. Palaeoecol. 108 (3-4), 195-205. doi:10. 1016/0031-0182(94)90233-x

Yeh, H.-W., and Savin, S. M. (1977). Mechanism of burial metamorphism of argillaceous sediments: 3. O-isotope evidence. Geol. Soc. Am. Bull. 88 (9), 1321-1330. doi:10.1130/0016-7606(1977)88<1321:mobmoa >2.0.co;2

Zachos, J., Pagani, M., Sloan, L., Thomas, E., and Billups, K. (2001). Trends, rhythms, and aberrations in global climate 65 Ma to present. Science 292 (5517), 686-693. doi:10.1126/science.1059412

Conflict of Interest: The authors declare that the research was conducted in the absence of any commercial or financial relationships that could be construed as a potential conflict of interest.

Copyright (C) 2021 McLean and Bershaw. This is an open-access article distributed under the terms of the Creative Commons Attribution License (CC BY). The use, distribution or reproduction in other forums is permitted, provided the original author(s) and the copyright owner(s) are credited and that the original publication in this journal is cited, in accordance with accepted academic practice. No use, distribution or reproduction is permitted which does not comply with these terms. 